\title{
Analisis Kinerja Keuangan Perusahaan Sektor Pertambangan Antara PMA dan PMDN Di Bursa Efek Indonesia
}

\author{
Abdul Basyith \\ Universitas Bina Darma \\ Email: basyith@binadarma.acid \\ Ismi Fadillah \\ PT Malta Satya Utama \\ Email: ismifadillah19@gmail.com
}

\begin{abstract}
This study aims to compare the financial performance between foreign and domestic mining firms in Indonesia for a period of 2012-2016. Not only comparing the financial performance, this study is also aimed at analyzing the impact of liquidity ratio, solvability ratio and activity ratio on financial performance and at analyzing which ratio provides the highest contribution on the financial performance of foreign and domestic mining firms in Indonesia for a period of 2012-2016. The total sample employed is 15 foreign firms (PMA) and 15 domestic firms (PMDN). The independent variable used is liquidity ratio, solvability ratio and activity ratio in which each proxies used are current ratio (CR), debt to equity ratio (DER) dan total assets turnover (TATO). Meanwhile the dependent variable used is profitability ratio in which proxies used are return on assets (ROA) dan return on equity (ROE). The analysis technique used in this study is independent samples t-test and multiple regression equation. The results reveal that: (1) There is no significance difference of variance value for all variables (CR, DER, TATO, ROA dan ROE) between foreign and domestic firms; (2) Apart from CR, TATO, ROA and ROE, only debt to equity ratio (DER) shows a significance difference for foreign and domestic firms; (3) CR, DER, TATO, ROA and ROE for foreign firms is better than domestic firms; (4)Ccurrent ratio $\left(\mathrm{X}_{1}\right)$, debt to equity ratio $\left(\mathrm{X}_{2}\right)$, and total assets turnover $\left(\mathrm{X}_{3}\right)$ have a positive and significant impact simultaneously on the financial performance for both return on assets (ROA) and return on equity (ROE) for foreign and domestic firms; (5) Total assets turnover $\left(\mathrm{X}_{3}\right)$ is the only variable providing the highest contribution to the improvement of financial performance for both return on assets and return on equity for foreign and domestic firms.
\end{abstract}

Keywords: Financial Performance, Mining Sector, State-owned Enteprise, Foreign Investment, Indonesia

\begin{abstract}
Abstrak
Penelitian ini bertujuan untuk membandingkan kinerja keuangan antara perusahaan pertambangan asing dan domestik di Indonesia periode 2012-2016. Tidak hanya itu, penelitian ini juga menganalisis pengaruh rasio likuiditas, rasio solvabilitas dan rasio aktivitas terhadap kinerja keuangan perusahaan serta menganalisis rasio manakah yang memberikan kontribusi paling besar terhadap kinerja keuangan perusahaan pertambangan asing dan domestik di Indonesia periode 2012-2016. Total sampel yang digunakan adalah 15 PMA dan 15 PMDN. Variabel independen dalam penelitian ini adalah rasio likuiditas, rasio solvabilitas dan rasio aktivitas dengan masing-masing proksi current ratio (CR), debt to equity ratio (DER) dan total assets turnover (TATO). Sedangkan variabel dependen adalah rasio profitabilitas yang diproksikan dengan return on assets (ROA) dan return on equity (ROE). Teknik analisis yang digunakan dalam penelitian ini adalah uji beda dua sampel (independent samples t-test) serta persamaan regresi berganda (multiple regression equation). Hasil penelitian menunjukkan bahwa: (1) tidak terdapat perbedaan secara signifikan nilai varian untuk semua variabel (CR, DER, TATO, ROA dan ROE) untuk kedua kelompok perusahaan PMA dan PMDN; (2) Hanya nilai rata-rata debt to equity ratio (DER) yang menunjukkan perbedaan secara signifikan antara kedua kelompok perusahaan (PMA dan PMDN) sedangkan nilai rata-rata CR, TATO, ROA dan ROE tidak menunjukkan perbedaan rata-rata yang signifikan; (3) Secara keseluruhan nilai rata-rata CR, DER, TATO, ROA dan ROE perusahaan PMA lebih baik dari pada perusahaan PMDN; (4) Variabel current ratio $\left(\mathrm{X}_{1}\right)$, debt to equity ratio $\left(\mathrm{X}_{2}\right)$, dan total assets turnover $\left(\mathrm{X}_{3}\right)$ secara bersama-sama berpengaruh positif dan signifikan terhadap variabel kinerja keuangan baik untuk return on assets maupun return on equity pada perusahaan pertambangan asing maupun
\end{abstract}




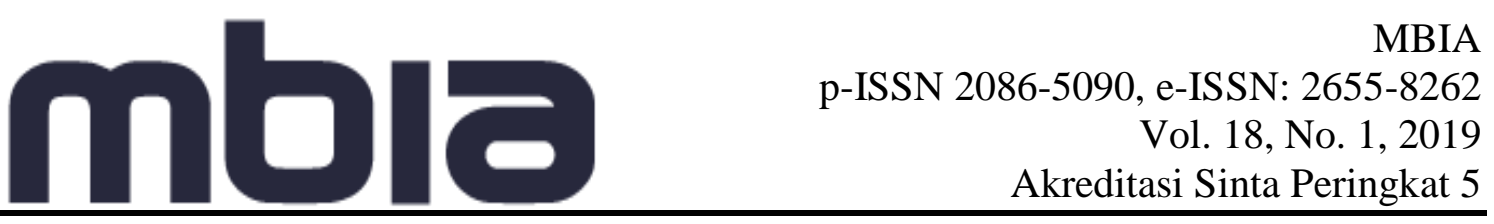

perusahaan pertambangan domestik; (5) Variabel total assets turnover $\left(\mathrm{X}_{3}\right)$ merupakan variabel yang memberikan kontribusi paling besar dibandingkan variabel independen lainnya terhadap peningkatan kinerja keuangan baik untuk return on assets maupun return on equity pada perusahaan pertambangan domestik maupun perusahaan pertambangan domestik.

Kata kunci: Kinerja Keuangan, Sektor Pertambangan, PMDN, PMA, Indonesia

\section{Pendahuluan}

Indonesia merupakan negara di Asia Tenggara yang memiliki kekayaan sumber daya alam yang tinggi terutama kekayaan tambang, sehingga hal tersebut membuat Indonesia menjadi negara dengan daya tarik tesendiri bagi investor untuk berinvestasi. Berdasarkan laporan Badan Pusat Statistik Tahun 2016, Sektor Industri pertambangan merupakan penyumbang pertumbuhan ekonomi Indonesia terbesar kelima, setelah sektor industri pengolahan, sektor industri usaha pertanian, kehutanan dan perikanan, sektor industri perdagangan besar-eceran, sektor industri konstruksi dan sektor industri pertambangan dan penggalian. Secara spesifik sektor industri pertambangan memberikan sumbangan sebesar 7,2 persen dari total Produk Domestik Bruto Indonesia.

Selain itu, sektor pertambangan merupakan sektor usaha yang memiliki karateristik usaha padat modal dan padat teknologi serta tidak dapat diperbaharui. Penggunaan padat modal dan padat teknologi menjadikan industri ini industri yang memiliki resiko yang tinggi. Tingginya resiko dalam industri ini juga dibarengi dengan peluang yang tinggi pula dikarenakan sektor pertambangan masih memiliki peluang untuk berkembang. Peningkatan jumlah negara-negara asia yang beralih menjadi investor di bidang pertambangan juga memberikan sumbangan terhadap perkembangan sektor industri pertambangan di tanah air.

Menurut UU Nomor 25 Tahun 2007 tentang penanaman modal, status perusahaan dapat dibedakan dalam 2 (dua) kategori kepemilikan yaitu PMA dan PMDN. Perusahaan PMA yaitu perusahaan yang sebagian besar sahamnya (pemegang saham pengendali) dimiliki oleh investor asing. Sedangkan PMDN adalah perusahaan yang sebagian besar sahamnya (pemegang saham pengendali) dimiliki oleh investor dalam negeri. Dengan adanya perbedaan status kepemilikan tersebut, maka perbedaan karakter dan budaya dari masingmasing investor serta gaya kepemimpinan akan mempengaruhi kinerja perusahaan melalui kebijakan manajemen yang diterapkan. Fiedler menemukan tiga dimensi kritis daripada situasi/lingkungan yang mempengaruhi gaya kepemimpinan yang sangat efektif, yaitu kekuasaan atas dasar kedudukan (jabatan), struktur tugas, dan hubungan antara pemimpin dan anggotanya.

Sebagian besar perusahaan sedang berjuang untuk mengoptimalkan bisnis mereka dalam ekonomi global dari berbagai aspek, dimana salah satunya dari segi leadership style, karena setiap gaya kepemimpinan yang berbeda-beda dapat mempengaruhi efektivitas organisasi atau kinerja organisasi (Nahavandi, 2002 dalam Chung, 2008). Seperti Chung dan Yang (2008) menyatakan bahwa perbedaan gaya kepemimpinan akan berdampak pada kinerja perusahaan, sedangkan di sisi lain banyak orang saat ini ingin mencari pemimpin yang menerapkan gaya kepemimpinan yang dapat mempromosikan cita-cita dan tanggung jawab lingkungan dan juga seorang pemimpin yang tidak hanya berusaha untuk mencegah sebuah kejadian memilukan yang membuat perusahaan tersebut disorot oleh masyarakat luas. Gaya kepemimpinan yang baik akan mempengaruhi sikap 
stakeholder dalam menciptakan laba perusahaan yang dicerminkan melalui kinerja keuangan. Gaya kepemimpinan memiliki hubungan yang lebih luas terhadap kinerja keuangan merupakan bagian dari Organizational Performance. Mayo dan Nohria (2005) berpendapat perusahaan yang tidak memiliki kemampuan untuk membaca dan beradaptasi pada perubahan kondisi bisnis, maka personalia dan kemampuan perusahaan hanya akan menjadi keunggulan sementara saja. Ketidakadaaan sensitivitas kontekstual akan menjadi penyebab jatuhnya perusahaan meskipun dipimpin oleh eksekutif sebaik apapun. Efektivitas kepemimpinan itu sendiri dilihat sebagai pengaruh yang berkepanjangan dari praktik manajemen dan bisnis. Efektivitas kepemimpinan dilihat sebagai salah satu faktor yang mempengaruhi perkembangan berkelanjutan (Quazi, 2001). Andersen (2002:3) menyatakan bahwa sebuah pandangan yang luas memiliki dampak yang besar terhadap keefektivan organisasi. Studi literatur mengenai kepemimpinan secara implisit didasarkan pada asumsi bahwa kepemimpinan merupakan penyebab dari organisasi yang efektif.

Perusahaan pertambangan merupakan perusahaan yang memiliki karakteristik khusus, oleh sebab itu perlu dilakukan penilaian kinerja perusahaan berupa gambaran mengenai kondisi keuangan suatu perusahaan yang mencerminkan prestasi yang telah dicapai perusahaan tersebut selama periode tertentu. Penilaian prestasi atau kinerja suatu perusahaan merupakan salah satu cara yang dapat dilakukan oleh manajemen agar dapat memenuhi kewajibannya terhadap para stakeholders dan juga untuk mencapai tujuan yang telah ditetapkan perusahaan.

Untuk menilai kinerja keuangan perusahaan dapat digunakan tolak ukur tertentu. Biasanya, ukuran yang digunakan adalah rasio atau indeks yang menghubungkan dua atau lebih data keuangan yang tercermin dalam laporan keuangan. Perbandingan rasio dapat dilakukan dengan dua cara, yaitu dengan membandingkan rasio masa lalu, saat ini dan masa yang akan datang untuk perusahaan yang sama atau membandingkan rasio antara satu perusahaan dengan perusahaan lain yang sejenis.

Penelitian ini mengacu pada penelitian yang telah dilakukan oleh Runtulalo (2013). Perbedaan penelitian dengan penelitian sebelumnya terletak pada periode penelitian dan objek penelitian. Pada periode penelitian, Runtulalo (2013) menggunakan periode penelitian tahun 2008 sampai dengan tahun 2011, sedangkan pada penelitian ini penulis akan menggunakan periode penelitian tahun 2012 sampai dengan 2016 agar diperoleh data yang lebih baru yang dapat menggambarkan kondisi terbaru. Kemudian, pada penelitian Runtulalo (2013), objek yang digunakan adalah perusahaan manufaktur domestik dan asing yang go public di Indonesia, sedangkan dalam penelitian ini penulis menggunakan objek perusahaan pertambangan asing dan domestik yang go public di Indonesia.

Berdasarkan latar belakang di atas, adapun tujuan penelitian ini adalah: (1) Untuk mengetahui apakah terdapat perbedaan kinerja keuangan antara perusahaan pertambangan asing dan domestik di Indonesia periode 2012-2016; (2) Untuk pengaruh rasio likuiditas, rasio solvabilitas dan rasio aktivitas terhadap kinerja keuangan perusahaan pertambangan asing dan domestik di Indonesia periode 2012-2016; (3) Untuk 


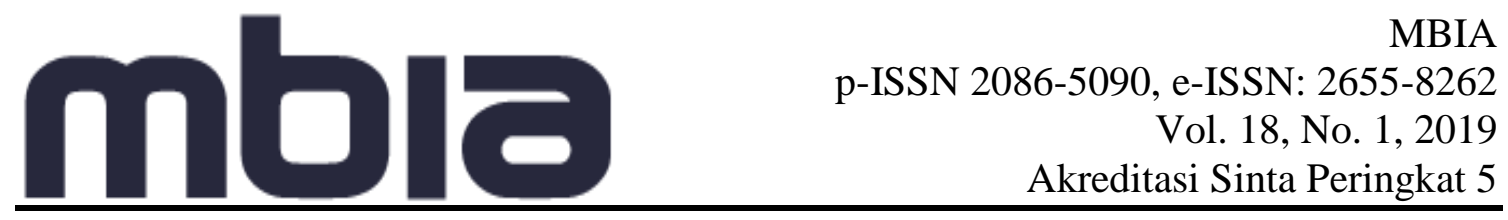

mengetahui rasio yang memberikan kontribusi paling besar terhadap kinerja keuangan perusahaan pertambangan asing dan domestik di Indonesia periode 2012-2016.

\section{Literature Review}

Jensen dan Meckling (1976) dalam Ulfiyati, Lambey, dan Walandouw (2017) menjelaskan bahwa pada agency theory pada sebuah perusahaan terdapat dua pihak yang saling berinteraksi. Pihak-pihak tersebut adalah pemilik perusahaan (pemegang saham) dan manajemen perusahaan. Pemegang saham disebut prinsipal, sedangkan manajemen perusahaan disebut sebagai agen. Perusahaan yang memisahkan fungsi pengelolaan dan kepemilikan akan rentan terhadap konflik keagenan (agency conflict) yang disebabkan karena masing-masing pihak mempunyai kepentingan yang saling bertentangan, yaitu berusaha mencapai kemakmurannya sendiri.

Konsep mengenai teori agensi muncul ketika terjadi pemisahan antara kepemilikan perusahaan dengan pengelolaan perusahaan, yaitu pemilik perusahaan atau pemegang saham sebagai principal dan manajemen sebagai agen atau sebagai pihak yang mengelola perusahaan. Tujuan dari pemisahan tersebut adalah agar principal memperoleh keuntungan semaksimal mungkin dengan biaya seefisien mungkin pada perusahaan yang dikelola oleh tenaga-tenaga profesional atau agen. Namun, dalam perkembangannya agen bertindak tidak sesuai dengan kepentingan principal sehingga akan timbul konflik yang dinamakan konflik keagenan atau konflik kepentingan.

Dapat disimpulkan berdasarkan teori mengenai masalah keagenan bahwa ketika terjadi pemisahan antara struktur kepemilikan perusahaan dan manajemen perusahaan, maka resiko munculnya konflik kepentingan yang berbeda baik antara pemilik perusahaan dan manajemen perusahaan ataupun antara pemilik perusahaan mayoritas dan pemilik perusahaan minoritas lebih tinggi dibandingkan perusahaan yang tidak melakukan pemisahan struktur kepemilikan dan manajemen usaha. Perbedaan kepentingan antara berbagai pihak inilah yang disebut sebagai masalah keagenan yang pada akhirnya dapat mempengaruhi kinerja keuangan perusahaan.

Beberapa penelitian yang telah dilakukan terkait dengan perbandingan kinerja keuangan perusahaan antara lain Runtulalo (2013) melakukan analisis komparasi kinerja keuangan perusahaan manufaktur domestik dan asing yang go public di Indonesia. Sampel yang digunakan sebanyak 14 perusahaan manufaktur domestik (PMDN) dan 14 perusahaan manufaktur asing (PMA). Hasil penelitian menunjukkan bahwa CR, DER, TATO, ROA dan ROE antara perusahaan manufaktur domestik dan asing tidak memiliki perbedaan.

Subaweh (2008) melakukan analisis perbandingan kinerja keuangan bank syariah dan bank konvensional periode 2003-2007. Penelitian dilakukan pada 3 bank syariah yang ada di Indonesia dan 20 bank konvensional dengan jumlah aktiva terbesar. Hasil penelitian menunjukkan bahwa tidak terdapat perbedaan kinerja yang signifikan antara bank konvensional dan bank syariah di Indonesia.

Asyikin dan Tanu (2011) melakukan analisis perbandingan kinerja keuangan perusahaan Farmasi milik BUMN dan swasta yang terdaftar di BEI periode 2005-2009. Sampel penelitian menggunakan 2 perusahaan BUMN dan 7 perusahaan swasta. Hasil penelitian 


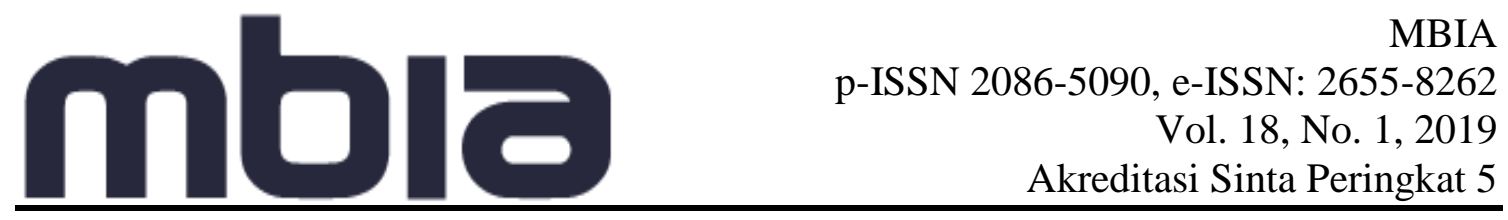

ini menunjukkan bahwa terdapat perbedaan yang signifikan antara perusahaan farmasu BUMN dan perusahaan farmasi swasta dimana perusahaan swasta memiliki kinerja keuangan yang lebih baik dibanding perusahaan BUMN.

Zulkifli dan Wujayanti (2014) melakukan analisis perbandingan rasio profitabilitas PMA dan PMDN pada perusahaan manufaktur yang terdaftar di BEI tahun 2011. Hasil dari peneltian ini menunjukkan bahwa terdapat perbedaan yang signifikan antara ROI dan ROE perusahaan manufaktur PMA dan perusahaan manufaktur PMDN di Bursa Efek Indonesia.

Ayunda (2014) menganalisis perbandingan kinerja keuangan perusahaan makanan dan minuman di BEI. Data yang digunakan adalah laporan keuangan perusahaan makanan dan minuman dari tahun 2009-2012. Berdasarkan perbandingan rasio likuiditas yang terdiri dari current ratio dan quick ratio, dapat diketahui bahwa PT. Akasha Wira Internasional Tbk mempunyai kinerja keuangan yang lebih baik. Berdasarkan perbandingan rasio aktivitas dapat diketahui bahwa jika dilihat dari total asset turn over, PT. Mayora Indah Tbk mempunyai kinerja keuangan yang lebih baik dan jika dilihat dari receivable turn over, PT. Multi Bintang Indonesia Tbk mempunyai kinerja keuangan yang lebih baik. Berdasarkan perbandingan rasio solvabilitas dapat diketahui bahwa jika dilihat dari debt to total assets ratio, PT. Indofood Sukses Makmur Tbk mempunyai kinerja keuangan yang lebih baik. Berdasarkan perbandingan rasio profitabilitas yang terdiri dari profit margin, Return On Assets, dan Return On Equity, PT. Multi Bintang Indonesia Tbk mempunyai kinerja keuangan yang lebih baik.

Purnamasari dan Ariyanto (2016) menganalisis perbandingan kinerja keuangan bank konvensional dan bank syariah periode 2010-2014. Sampel penelitian terdiri dari 31 perusahaan perbankkan konvensional dan 11 perusahaan perbankkan syariah. Hasil analisis uji beda pada penelitian ini menunjukkan ada perbedaan yang signifikan antara kinerja keuangan bank konvensional dan bank syariah.

Wahyuni dan Efriza (2017) yang meneliti perbandingan kinerja keuangan bank syairah dan bank konvensional di Indonesia dengan menggunakan sampel 12 bank konvensional dan 9 bank syariah. Hasil dari penelitian ini menunnjukkan bahwa berdasarkan rata-rata rasio CAR, ROA, ROE, NPL, BOPO, dan LDR yang digunakan terdapat perbedaan yang signifikan antara bank syariah dan bank konvensional. Namun secara keseluruhan kinerja perbankkan syariah lebih baik dibanding perbankkan konvensional pada periode penelitian 2011-2014.

Tiasita dan Wiagustini (2017) melakukan penelitian komparatif terhadap kinerja keuangan pada perusahaan domestik dan perusahaan multinasional sektor manufaktur yang terdafta di BEI tahun 2013-2015. Sampel penelitian sebanyak 50 perusahaan domestik dan 50 perusahaan multinasional. Hasil penelitian menunjukkan bahwa kinerja keuangan perusahaan domestik dan perusahaan multinasional yang dinilai dengan menggunak CR, Fixxed Assets Turnover, DER, ROA, dan PBV tidak memiliki perbedaan yang signifikan. 


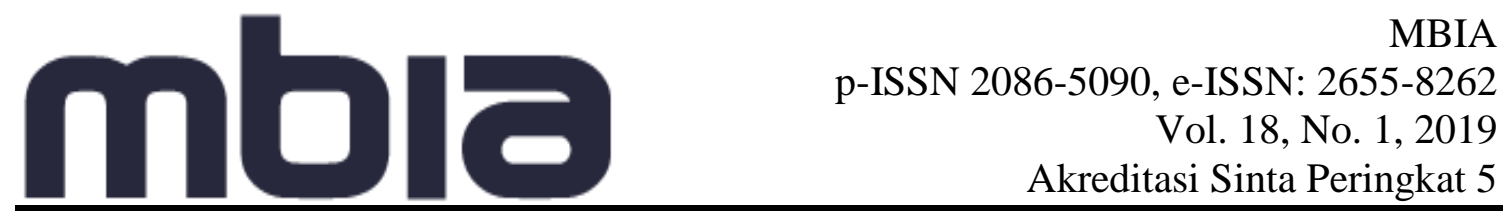

Mardiyani (2017) melakukan analisis perbandingan kinerja keuangan perusahaan Farmasi milik BUMN dan swasta yang terdaftar di BEI periode 2010-2014. Penelitian menggunakan 8 sampel. yaitu 2 perusahaan farmasi BUMN dan 6 perusahaan farmasi swasta. Hasil dari penelitian ini menunjukkan bahwa terdapat perbedaan signifikan jika dilihat berdasarkan ROE dan EPS masing-masing perusahaan, namun untuk nilai EVA baik perusahaan BUMN maupun swasta tidak terdapat perbedaan yang signifikan.

Ulfiyati, Lambey, dan Walandouw (2017) menganalisis perbedaan struktur kepemilikan asing dan struktur kepemilikan domestik pada perusahaan pertambangan di BEI. Penelitian dilakukan selama periode 2013-2015 dengan sampel penelitian sebanyak 37 perusahaan tambang. Hasil dari penelitian menunjukkan bahwa pada variabel ROA terdapat perbedaan yang signifikan sedangkan pada variabel ROE dan NPM tidak terdapat perbedaan signifikan antara perusahaan tambang asing dan domestik di BEI.

\section{Metodologi Penelitian}

Penelitian ini merupakan penelitian komparatif, yaitu penelitian yang bersifat membandingkan. Pada penelitian ini, variabelnya masih mandiri tetapi untuk sampel yang lebih dari satu atau dalam waktu yang berbeda (Runtulalo, 2013). Penelitian ini menggunakan jenis data kuantitatif yang berasal dari data sekunder berupa laporan keuangan dari tahun 2012 sampai dengan tahun 2016. Data sekunder dalam penelitian ini diperoleh dengan mengakses website Bursa Efek Indonesia yaitu www.idx.co.id.

Dalam penelitian ini populasi yang diteliti adalah perusahaan sektor pertambangan yang terdaftar di BEI. Jumlah populasi dalam penelitian ini adalah sebanyak 41 perusahaan. Sektor pertambangan terdiri dari 4 subsektor yaitu (1) Subsektor pertambangan batubara, (2) Subsektor pertambangan minyak dan gas bumi, (3) Subsektor pertambangan logam dan mineral lainnya, serta (4) Subsektor pertambangan batu-batuan. Dari total populasi sebanyak 41 perusahaan, terdapat 17 perusahaan PMA, 21 perusahaan PMDN dan 3 perusahaan BUMN. Penelitian ini hanya menggunakan perusahaan PMA dan PMDN untuk melihat perbandingan kinerja keuangan antara perusahaan PMA dan PMDN.

Teknik pengambilan sampel dalam penelitian ini menggunakan teknik purposive sampling, yaitu dengan teknik pengambilan sampel yang didasarkan pada kriteria-kriteria tertentu (Sanusi, 2011). Kriteria-kriteria tersebut, antara lain (1) Perusahaan PMA dan PMDN telah terdaftar (Initial Public Offerings) di Bursa Efek Indonesia minimal sudah 5 tahun, (2)Perusahaan terdaftar di BEI selama Januari 2012 - Desember 2016, (3) Perusahaan mempublikasikan data laporan keuangannya selama periode 2012-2016 secara lengkap, (4) Perusahaan berstatus perusahaan penanaman modal dalam negeri (PMDN) dan penanaman modal asing (PMA) secara konsisten dan berturut-turut selama periode 2012-2016.

Berdasarkan kriteria pengambilan sampel tersebut diatas, maka sampel dalam penelitian ini adalah 15 perusahaan PMA dimana 2 perusahaan PMA tidak memenuhi kriteria pengambilan sampel dan 15 perusahaan PMDN dimana 6 perusahaan PMDN tidak memenuhi kriteria pengambilan sampel diatas. 


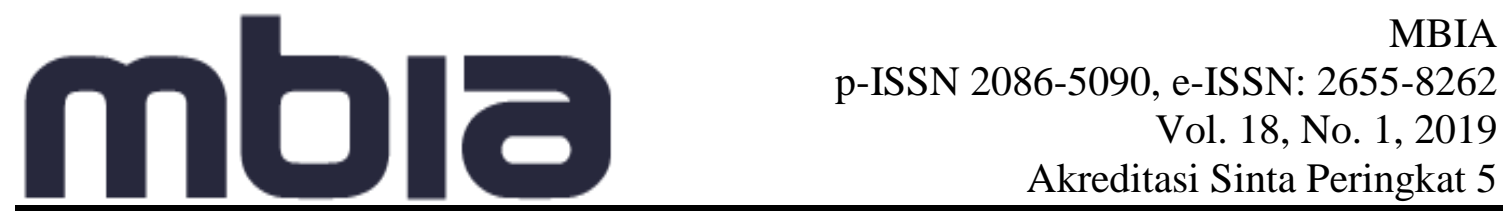

Variabel independen dalam penelitian ini adalah rasio likuiditas dengan menggunakan current ratio, rasio solvabilitas dengan menggunakan debt to equity ratio dan rasio aktivitas dengan menggunakan total assets turnover. Variabel dependen dalam penelitian ini adalah rasio profitabilitas yang diproksikan return on assets dan return on equity.

Model analisis data yang digunakan dalam penelitian ini adalah uji beda dua sampel (independent samples t-test) dan persamaan regresi berganda (multiple regression equation). Adapun model persamaan regresi berganda dalam penelitian ini adalah:

Persamaan 1

$y_{1 i t}=\alpha+\beta_{1} X_{1 i t}+\beta_{2} X_{2 i t}+\beta_{3} X_{3 i t}+\varepsilon_{i t}$

Persamaan 2

$y_{2 i t}=\alpha+\beta_{1} X_{1 i t}+\beta_{2} X_{2 i t}+\beta_{3} X_{3 i t}+\varepsilon_{i t}$

Keterangan:

$\alpha \quad=$ Konstanta

$\beta_{1} \quad=$ koefisien regresi $\mathrm{CR}$

$\beta_{2} \quad=$ koefisien regresi DER

$\beta_{3} \quad=$ koefisien regresi TATO

$X_{1 i t}=$ Current ratio $(\mathrm{CR})$

$X_{2 i t}=$ Debt equity ratio $(\mathrm{DER})$

$X_{3 i t}=$ Total asset turnover (TATO)

$Y_{1 i t} \quad=$ Return on Assets (ROA)

$Y_{2 i t} \quad=$ Return on Equity (ROE)

$e_{i t} \quad=$ Error term (faktor pengganggu)

\section{Hasil dan Pembahasan}

Berikut disajikan hasil statistik deskriptif untuk variabel CR, DER, TATO, ROA dan ROE untuk kelompok PMA dan PMDN.

Tabel 1. Hasil Deskriptif Statistik PMA

\begin{tabular}{|l|r|r|r|r|r|r|}
\hline & N & Range & Minimum & Maximum & \multicolumn{1}{c|}{ Mean } & Std. Deviation \\
\hline Current Ratio & 75 & 7771,13 & 29,28 & 7800,41 & 534,4477 & 1335,83585 \\
Debt to Equity Ratio & 75 & 4,83 &, 01 & 4,84 & 1,1897 & 1,17295 \\
Total Assets Turnover & 75 & 5,08 &, 01 & 5,09 &, 8119 & 1,07316 \\
Return on Assets & 75 & 94,40 & $-65,43$ & 28,97 &, 7544 & 13,13428 \\
Return on Equity & 75 & 761,80 & $-146,84$ & 614,96 & 7,6559 & 75,86680 \\
Valid N (listwise) & 75 & & & & & \\
\hline
\end{tabular}

Tabel 1 menjelaskan statistik deskriptif dari masing-masing variabel yang diteliti untuk kelompok Perusahaan Modal Asing (PMA). Rata-rata Current Rasio PMA adalah 534,4477. Nilai current adalah 534,4477 ini menunjukkan bahwa setiap satu rupiah current liabiliti dijamin oleh current asset sebesar rp. 534,447. Dengan nilai minimum sebesar 29,28 dan nilai maksimum 7800,41. Terjadinya perbedaan antara nilai maksimum dan nilai minimum yang sangat jauh ini dikarena ada satu perusahaan yang mempunyai nilai current ration yang extreem. Perusahaan tersebut adalah INCO, oleh karena itu Perusahaan ini INCO akan dikeluarkan dari perhitungan. Nilai rata-rata Debt to Equity 
Ratio untuk perusahaan PMA adalah 1,1897, dengan nilai minimum sebesar 0,1 dan nilai maksimum 4,84. Nilai rata-rata 1,1897 ini menunjukkan bahwa jumlah debt lebih besar dari jumlah equity. Jarak antara nilai maksimum dan nilai minimum masih dalam jarak yang rasional. Nilai rata-rata Total Asset turnover (TATO) adalah sebesar 0,8119. Hal ini menunjukkan bahwa total penjualan PMA lebih kecil dari pada total aset. Nilai minimum adalah sebesar 0,1 dan nilai maksimum adalah 5,09. Perbedaan nilai minimum dan maksimum ini masih dalam range yang relevan. Nilai rata-rata Return on Asset untuk perusahaan PMA adalah 0,7544, ini berarti bahwa setiap satu rupiah asset dapat memberikan kontribusi pendapatan sebesar 0,7544 rupiah. Nilai rata-rata Return on Equity (ROE) untuk perusahaan PMA adalah 7,6559, hal ini menunjukkan bahwa setiap satu rupiah equity dapat memberikan kontribusi terhadap laba perusahaan adalah sebesar Rp. 7,6559. Berikut disajikan hasil statistik deskriptif untuk PMDN.

Tabel 1. Hasil Deskriptif Statistik PMDN

\begin{tabular}{|l|r|r|r|r|r|r|}
\hline & N & Range & Minimum & Maximum & \multicolumn{1}{c|}{ Mean } & $\begin{array}{c}\text { Std. } \\
\text { Deviation }\end{array}$ \\
\hline Current Ratio & 75 & 2006,85 & 9,90 & 2016,75 & 277,7197 & 370,47103 \\
Debt to Equity Ratio & 75 & 52,31 & $-24,12$ & 28,19 & 2,3741 & 6,20237 \\
Total Assets Turnover & 75 & 1,93 &, 01 & 1,94 &, 5183 &, 42678 \\
Return on Assets & 75 & 112,39 & $-64,39$ & 48,00 &,- 2083 & 12,73040 \\
Return on Equity & 75 & 397,83 & $-179,94$ & 217,89 & 1,2701 & 39,75857 \\
Valid N (listwise) & 75 & & & & & \\
\hline
\end{tabular}

Tabel 2 menjelaskan statistik deskriptif dari masing-masing variabel yang diteliti untuk kelompok Perusahaan Modal Dalam Negeri (PMDN). Rata-rata Current Rasio PMA adalah 277,7197. Nilai current adalah 277,7197 ini menunjukkan bahwa setiap satu rupiah current liabiliti dijamin oleh current asset sebesar rp. 277,7197. Hal ini menunjukkan bahwa likuiditas perusahaan PMDN sangat baik. Dengan nilai minimum sebesar 9,90 dan nilai maksimum 2016,75. Terjadinya perbedaan antara nilai maksimum dan nilai minimum yang sangat jauh ini dikarena ada satu perusahaan yang mempunyai nilai current ration yang extreem. Perusahaan tersebut adalah DKFT, oleh karena itu Perusahaan ini DKFT akan dikeluarkan dari perhitungan. Nilai rata-rata Debt to Equity Ratio untuk perusahaan PMDN adalah 2,3741, dengan nilai minimum sebesar -24,12 0,1 dan nilai maksimum 28,19. Nilai rata-rata 2,3741 ini menunjukkan bahwa jumlah debt lebih besar 2 kali dari pada jumlah equity. Jarak antara nilai maksimum dan nilai minimum masih dalam jarak yang rasional. Nilai rata-rata Total Asset turnover (TATO) adalah sebesar 0,5183 Hal ini menunjukkan bahwa total penjualan PMDN lebih kecil dari pada total aset. Nilai minimum adalah sebesar 0,01 dan nilai maksimum adalah 1,94. Perbedaan nilai minimum dan maksimum ini masih dalam range yang relevan. Nilai ratarata Return on Asset untuk perusahaan PMDN adalah -0,2083, ini berarti bahwa setiap satu rupiah asset dapat memberikan kontribusi kerugian sebesar 0,2083 rupiah. Nilai ratarata Return on Equity (ROE) untuk perusahaan PMDN adalah 1,2701, hal ini menunjukkan bahwa setiap satu rupiah equity dapat memberikan kontribusi terhadap laba perusahaan adalah sebesar Rp. 1,2701.

\section{Independent Sample mean t-test}

Hasil nilai rata-rata dan uji beda penelitian yang dilakukan ditampilkan pada tabel berikut. 
MBIA

p-ISSN 2086-5090, e-ISSN: 2655-8262

Vol. 18, No. 1, 2019

Akreditasi Sinta Peringkat 5

Tabel 3. Group Statistics

\begin{tabular}{|ll|r|r|r|r|}
\hline & KELOMPOK & \multicolumn{1}{|c|}{ N } & \multicolumn{1}{c|}{ Mean } & Std. Deviation & Std. Error Mean \\
\hline LN_PMA_CR & PMA & 75 & 5,3298 & 1,10686 &, 12781 \\
& PMDN & 75 & 5,0359 & 1,11682 &, 12896 \\
\hline LN_PMA_DER & PMA & 75 &,- 4211 & 1,30241 &, 15039 \\
& PMDN & 71 &, 1203 & 1,44849 &, 17190 \\
\hline LN_PMA_TATO & PMA & 75 &,- 8944 & 1,32264 &, 15272 \\
& PMDN & 75 & $-1,0716$ & 1,05046 &, 12130 \\
\hline LN_PMA_ROA & PMA & 53 &, 9525 & 1,75092 &, 24051 \\
& PMDN & 42 &, 9388 & 1,58405 &, 24442 \\
\hline LN_PMA_ROE & PMA & 54 & 1,6018 & 1,82862 &, 24884 \\
& PMDN & 42 & 1,9982 & 1,64229 &, 25341 \\
\hline
\end{tabular}

Tabel 3. di atas, menggambarkan rata-rata masing-masing variabel untuk kelompok PMA dan PMDN. Rata-rata CR, ROA dan ROE untuk kedua kelompok mempunyai nilai positif dan ralatif hampir sama, sedangkan nilai TATO adalah negatif akan tetapi juga relatif hampir sama. Sedangkan nilai DER untuk kelompok PMA bernilai negatif dan nilai DER untuk PMDN adalah positif.

Tabel 4. Independent Sample t-test Independent Samples Test

\begin{tabular}{|c|c|c|c|c|c|c|}
\hline & \multicolumn{2}{|c|}{$\begin{array}{c}\text { Levene's Test for } \\
\text { Equality of } \\
\text { Variances }\end{array}$} & \multicolumn{3}{|c|}{ t-test for Equality of Means } \\
\hline & & $\mathrm{F}$ & Sig. & $\mathrm{t}$ & $\mathrm{df}$ & Sig. (2-tailed) \\
\hline LN_CR & $\begin{array}{l}\text { Equal variances } \\
\text { assumed } \\
\text { Equal variances not } \\
\text { assumed }\end{array}$ & ,062 & 804 & 1,619 & 148 &, 108 \\
\hline LN_DER & $\begin{array}{l}\text { Equal variances } \\
\text { assumed } \\
\text { Equal variances not } \\
\text { assumed }\end{array}$ &, 330 &, 567 & $-2,377$ & 144 &, 019 \\
\hline LN_TATO & $\begin{array}{l}\text { Equal variances } \\
\text { assumed } \\
\text { Equal variances not } \\
\text { assumed }\end{array}$ & 1,674 & 198 & ,909 & 148 &, 365 \\
\hline
\end{tabular}




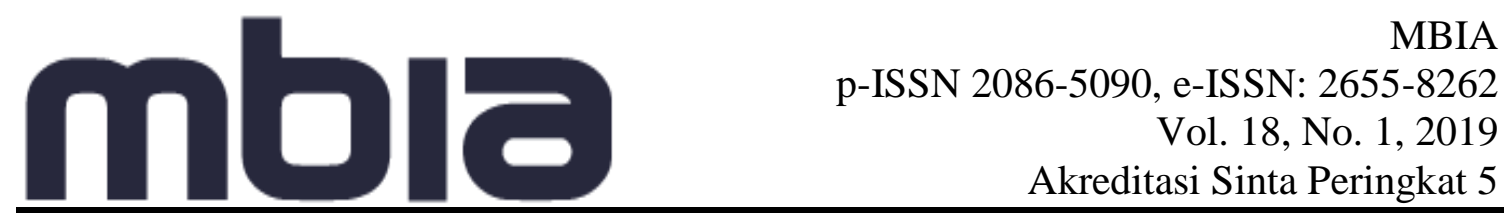

\begin{tabular}{|c|c|c|c|c|c|c|}
\hline LN_ROA & $\begin{array}{l}\text { Equal variances } \\
\text { assumed } \\
\text { Equal variances not } \\
\text { assumed }\end{array}$ & 1,062 &, 305 & ,039 & 93 & ,969 \\
\hline LN_ROE & $\begin{array}{l}\text { Equal variances } \\
\text { assumed } \\
\text { Equal variances not } \\
\text { assumed }\end{array}$ & ,472 & ,494 & $-1,101$ & 94 &, 274 \\
\hline
\end{tabular}

Sumber: data diolah

Berdasarkan Tabel 4 di atas, dapat dilihat bahwa:

\section{Current Ratio}

Berdasarkan nilai signifikan uji Levine adalah sebesar 0,804 ini berarti nilai ini adalah lebih besar dari pada nilai signifikan alpha $5 \%$, artinya varian kedua kelompok tidak ada beda. Hasil uji independen sample mean t test bahwa rata-rata Current Ratio untuk kelompok PMA dan PMDN adalah tidak ada beda. Hal ini dapat dijelaskan bahwa nilai rata-rata untuk PMA 534,4477 dan nilai rata-rata CR untuk PMDN adalah 277,7197. Walaupun hasil menunjukkan tidak ada beda, namun nilai Current Ratio perusahaan PMA lebih besar dari pada nilai Current Ratio perusahaan PMDN, ini menunjukkan tingkat likuiditas perusahaan PMA lebih bagus dari pada perusahaan PMDN. Penelitian ini juga memberikan hasil yang sama dengan penelitian yang dilakukan oleh Rantulalo (2013), Tiastita dan Wiagustini (2017) bahwa current rasio perusahaan asing tidak memiliki perbedaan signifikan dengan perusahaan PMDN. Tidak adanya perbedaan dalam current rasio ini juga menunjukan bahwa kedua kelompok perusahaan berusaha menjaga tingkat likuiditas pada tingkat yang aman, karena kesulitan lukuiditas akan berpengaruh terhadap operasional perusahaan.

\section{Debt Equity Ratio}

Berdasarkan nilai signifikan uji Levine adalah sebesar 0,567 ini berarti nilai ini adalah lebih besar dari pada nilai signifikan alpha $5 \%$, artinya varian untuk variabel DER kedua kelompok tidak ada beda. Hasil uji independen sample mean $t$ test menunjukkan bahwa variabel debt to equity rasio kedua kelompok perusahaan menunjukkan ada beda. Bila dilihar rata-rata DER untuk PMA sebesar 1,1897 dan nilai rata-rata DER untuk PMDN sebesar 2,3741. Perbedaan kedua nilai ra-rata ini cukup besar sehingga ini yang dapat menyebabkan nilai DER kedua kelompok perusahaan ini berbeda. Bila dilihat dari nilai DER, maka nilai DER untuk PMDN lebih besar dari DER untuk PMA. Hal ini menunjukkan bahwa perusahaan PMDN lebih banyak menggunakan data utang dari yaitu 2 kali lebih besar menggunakan utang dari pada equity, sedangkan PMA menggunakan utang hanya 1 kali lebih besar dari pada utang. Penggunaan utang yang lebih besar ini menunjukkan juga risiko yang lebih besar, artinya perusahaan pertambangan PMDN lebih berisiko daripada perusahaan pertambangan PMA. Hasil penelitian ini berbeda dengan hasil penelitian yang dilakukan oleh Rantulalo (2013), dan Tiasta dan Wiagustuti 


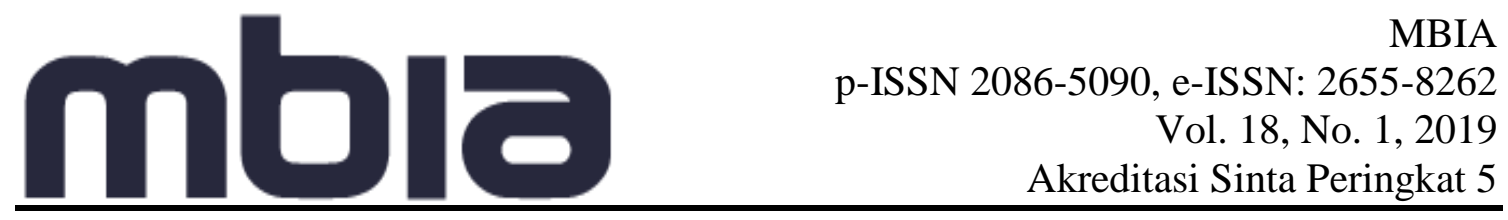

(2017). Penelitian Rantulalo dan Tiasta dan Wiagustuti memberikan hasil bahwa DER untuk kelompok perusahaan PMA dan PMDN adalah tidak ada beda.

\section{Total Asset Turnover}

Berdasarkan nilai signifikan uji Levine adalah sebesar 0198 ini berarti nilai ini adalah lebih besar dari pada nilai signifikan alpha $5 \%$, artinya varian variabel TATO kedua kelompok tidak ada beda. Hasil uji independen sample mean t test untuk variabel TATO untuk kedua kelompok perusahaan menunjukkan hasil bahwa TATO kedua perusahaan tidak ada perbedaan signifikan. Rata-rata TATO untuk perusahaan PMA adalah 0,8119 dan TATO untuk perusahaan PMDN adalah 0,5183. Nilai rata-rata TATO kedua perusahaan ini tidak jauh berbeda. Ini menunjukkan bahwa tingkat atau kontribusi total asset dalam mendukung penjualan kedua kelompok ini relatif sama. Namun demikian kelompok PMA menunjukkan kinerja kontribusi yang lebih bagus karena nilai rata-rata TATO perusahaan PMA lebih besar dari pada nilai rata-rata TATO PMDN. Hasil penelitian sama dengan hasil penelitian yang dilakukan oleh Rantulalo dan Tiasita dan Wiagustini, bahwa nilai TATO untuk perusahaan PMA dan PMDN tidak menunjukkan perbedaan yang signifikan.

\section{Return on Assets}

Berdasarkan nilai signifikan uji Levine adalah sebesar 0305 ini berarti nilai ini adalah lebih besar dari pada nilai signifikan alpha $5 \%$, artinya varian variabel ROA kedua kelompok tidak ada beda. Hasil uji independen sample mean t test untuk variabel ROA menunjukkan hasil bahwa ROA untuk PMA dan PMDN tidak menunjukkan perbedaan yang signifikan. Rata-rata ROA untuk PMA adalah 0,7544 dan nilai rata-rata ROA untuk PMDN adalah -,2083. Kedua ini mempunyai jarak yang cukup signinifikan, namun karena data ROA untuk PMA dan PMDN ini tidak berdistribusi normal maka ini yang dapat menyebabkan nilai rata-rata ROA kedua kelompok tersebut tidak berbeda. Namun demikian nilai ROA untuk perusahaan PMA positif, artinya secara keseluruhan perusahaan PMA mendapat laba yang positif, sedangkan ROA untuk perusahaan PMDN adalah negatif, ini berarti secara keseluruhan perusahaan PMDN banyak menderita kerugian. Ini juga menunjukkan bahwa perusahaan PMA lebih effisien dari pada perusahaan PMDN dalam menggunakan assetnya untuk mendapatkan laba. Penelitian ini juga mendukung hasil peneltian yang dilakukan oleh Rantulalo dan Tiasita dan Wiagustini, yang mana hasil penelitian menunjukkan bahwa ROA untuk perusahaan manufactur kelompok PMA dan PMDN tidak ada perbedaan signifikan. Namun hasil penelitian ini berbeda dengan hasil penelitian yang dilakukan oleh Zulkifli dan Wujayanti (2014) dan Ulfiyanti Lambey dan Wulandow (2017). Hasil peneitian Zulkifli dan Wujayanti yag melakukan penelitian pada perusahaan Farmasi dan Ulfiyanti Lamber \& Wulandaw (2017) menunjukkan ROA (ROI) untuk PMA dan PMDN ada beda.

\section{Return on Equity}

Berdasarkan nilai signifikan uji Levine adalah sebesar 0,494 ini berarti nilai ini adalah lebih besar dari pada nilai signifikan alpha $5 \%$, artinya varian variabel ROE kedua kelompok tidak ada beda. Hasil uji independen sample mean t test untuk variabel ROe menunjukkan hasil bahwa ROE untuk PMA dan PMDN tidak menunjukkan perbedaan yang signifikan. Rata-rata ROA untuk PMA adalah 7,6559 dan nilai rata-rata ROE untuk PMDN adalah 1,2701. Kedua ini mempunyai jarak yang cukup signinifikan, namun 
karena data ROE untuk PMA dan PMDN ini tidak berdistribusi normal maka ini yang dapat menyebabkan nilai rata-rata ROE kedua kelompok tersebut tidak berbeda. Namun demikian nilai ROE untuk perusahaan PMA dan PMDN positif, artinya secara keseluruhan perusahaan PMA mendapat laba yang positif, Ini juga menunjukkan bahwa perusahaan PMA lebih effisien dari pada perusahaan PMDN dalam menggunakan assetnya untuk mendapatkan laba. Penelitian ini juga mendukung hasil penelitian yang dilakukan oleh Rantulalo dan Tiasita dan Wiagustini, yang mana hasil penelitian menunjukkan bahwa ROA untuk perusahaan manufactur kelompok PMA dan PMDN tidak ada perbedaan signifikan. Namun hasil penelitian ini berbeda dengan hasil penelitian yang dilakukan oleh Mardiyanti (2017), Zulkifli dan Wujayanti (2014) dan Ulfiyanti Lambey dan Wulandow (2017). Hasil penelitian Mardiyanti, Zulkifli dan Wujayanti yang melakukan penelitian pada perusahaan manufactur dan Farmasi dan Ulfiyanti Lamber \& Wulandaw (2017) menunjukkan ROA (ROI) untuk PMA dan PMDN ada beda.

\section{Model Persamaan Regresi Berganda}

1) Perusahaan Pertambangan Asing: Return on Assets (ROA)

Berikut hasil persamaan regresi berganda dengan ROA sebagai variabel independen: $Y=0,200+0,188 X_{1}+0,008 X_{2}+0,554 X_{3}$

\begin{tabular}{|ll|r|r|r|r|r|}
\hline \multirow{2}{*}{ Model } & \multicolumn{2}{|c|}{$\begin{array}{c}\text { Unstandardized } \\
\text { Coefficients }\end{array}$} & $\begin{array}{c}\text { Standardized } \\
\text { Coefficients }\end{array}$ & & \multirow{2}{*}{ S } \\
\cline { 3 - 6 } & \multicolumn{1}{c|}{ B } & Std. Error & Beta & \multicolumn{1}{c|}{ Sig. } \\
\hline 1 & (Constant) &, 200 &, 543 & &, 368 &, 714 \\
& Current Ratio &, 188 &, 114 &, 199 & 1,649 &, 104 \\
& Debt to Equity Ratio &, 008 &, 140 &, 007 &, 058 &, 954 \\
& Total Assets Turnover &, 554 &, 122 &, 498 & 4,528 &, 000 \\
\hline
\end{tabular}

a. Dependent Variable: Return on Assets

Jika dilihat dari nilai standardized coefficients beta, nilai total assets turnover $\left(\mathrm{X}_{3}\right)$ merupakan nilai yang terbesar $(0,498)$ dibandingkan dengan dua variabel independen lainnya, sehingga dapat disimpulkan bahwa total assets turnover memberikan kontribusi paling besar terhadap peningkatan kinerja keuangan (return on assets) perusahaan pertambangan asing. Berdasarkan hasil perhitungan regresi linear berganda diperoleh nilai t hitung $1,649>\mathrm{t}$ tabel $1,666,(\mathrm{df}=5 \% ; 71)$ dengan level signifikan $0,104>\operatorname{sig} \alpha 0,05$ maka Ho tidak dapat ditolak artinya variabel current ratio $\left(\mathrm{X}_{1}\right)$ tidak berpengaruh secara signifikan terhadap variabel kinerja keuangan (return on assets) pada perusahaan pertambangan asing. Sedangkan nilai t hitung untuk variabel debt to equity ratio $\left(\mathrm{X}_{2}\right)$, adalah $0,058>\mathrm{t}$ tabel 1,666, $(\mathrm{df}=3 ; 71 ; 5 \%)$ dengan level signifikan $0,954<\operatorname{sig} \alpha 0,05$ maka Ho tidak dapat ditolak artinya variabel debt to equity ratio $\left(\mathrm{X}_{2}\right)$ tidak berpengaruh secara signifikan terhadap variabel kinerja keuangan (return on assets) pada perusahaan pertambangan asing. Sedangkan nilai t hitung untuk variabel total assets turnover $\left(\mathrm{X}_{3}\right)$, adalah 4,528>t tabel 1,666, $(\mathrm{df}=3 ; 71 ; 5 \%)$ dengan level signifikan $0,000<\operatorname{sig} \alpha 0,05$ maka Ho ditolak artinya variabel total assets turnover $\left(\mathrm{X}_{3}\right)$ berpengaruh secara signifikan terhadap variabel kinerja keuangan (return on assets) pada perusahaan pertambangan asing. 


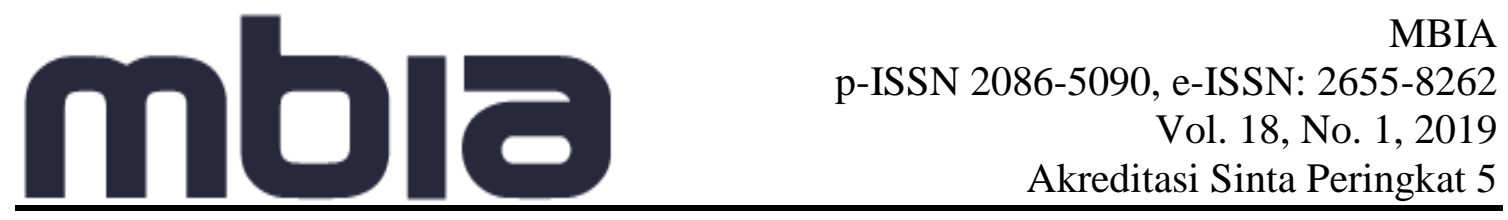

2) Perusahaan Pertambangan Asing: Return on Equity (ROE)

Berikut hasil persamaan regresi berganda dengan ROE sebagai variabel independen: $Y=0,315+0,280 X_{1}+0,297 X_{2}+0,545 X_{3}$

\begin{tabular}{|ll|r|r|r|r|r|}
\hline \multirow{2}{*}{ Model } & \multicolumn{2}{|c|}{$\begin{array}{c}\text { Unstandardized } \\
\text { Coefficients }\end{array}$} & $\begin{array}{c}\text { Standardized } \\
\text { Coefficients }\end{array}$ & & \\
\cline { 3 - 7 } & \multicolumn{1}{c|}{ B } & Std. Error & Beta & \multicolumn{1}{c|}{ t } & Sig. \\
\hline 1 & (Constant) &, 315 &, 614 & &, 513 &, 610 \\
& Current Ratio &, 280 &, 129 &, 263 & 2,173 &, 033 \\
& Debt to Equity Ratio &, 297 &, 158 &, 227 & 1,877 &, 065 \\
& Total Assets Turnover &, 545 &, 140 &, 432 & 3,896 &, 000 \\
& & & & &
\end{tabular}

a. Dependent Variable: Return on Equity

Jika dilihat dari nilai standardized coefficients beta, nilai total assets turnover $\left(\mathrm{X}_{3}\right)$ merupakan nilai yang terbesar $(0,432)$ dibandingkan dengan dua variabel independen lainnya, sehingga dapat disimpulkan bahwa total assets turnover memberikan kontribusi paling besar terhadap peningkatan kinerja keuangan (return on assets) perusahaan pertambangan asing. Berdasarkan hasil perhitungan regresi linear berganda diperoleh nilai t hitung 2,173>t tabel 1,666, $(\mathrm{df}=5 \%$; 71) dengan level signifikan $0,033<\operatorname{sig} \alpha 0,05$ maka Ho ditolak artinya variabel current ratio $\left(\mathrm{X}_{1}\right)$ berpengaruh secara signifikan terhadap variabel kinerja keuangan (return on equity) pada perusahaan pertambangan asing. Sedangkan nilai $t$ hitung untuk variabel debt to equity ratio $\left(\mathrm{X}_{2}\right)$, adalah $1,877>\mathrm{t}$ tabel 1,666, $(\mathrm{df}=3 ; 71 ; 5 \%)$ dengan level signifikan $0,065<\operatorname{sig} \alpha 0,10$ maka Ho ditolak artinya variabel debt to equity ratio $\left(\mathrm{X}_{2}\right)$ berpengaruh secara signifikan terhadap variabel kinerja keuangan (return on equity) pada perusahaan pertambangan asing. Sedangkan nilai $t$ hitung untuk variabel total assets turnover $\left(X_{3}\right)$, adalah 3,896> t tabel 1,666, $(\mathrm{df}=3 ; 71 ; 5 \%)$ dengan level signifikan $0,000<\operatorname{sig} \alpha 0,10$ maka Ho ditolak artinya variabel total assets turnover $\left(\mathrm{X}_{3}\right)$ berpengaruh secara signifikan terhadap variabel kinerja keuangan (return on equity) pada perusahaan pertambangan asing.

\section{3) Perusahaan Pertambangan Domestik: Return on Assets (ROA)}

Berikut hasil persamaan regresi berganda dengan ROA sebagai variabel independen: $Y=0,369+0,136 X_{1}-0,041 X_{2}+0,514 X_{3}$

\begin{tabular}{|ll|r|r|r|r|r|}
\hline \multirow{2}{*}{ Model } & \multicolumn{2}{|c|}{$\begin{array}{c}\text { Unstandardized } \\
\text { Coefficients }\end{array}$} & \multicolumn{2}{c|}{$\begin{array}{c}\text { Standardized } \\
\text { Coefficients }\end{array}$} & \multirow{2}{*}{} \\
\cline { 3 - 6 } & \multicolumn{1}{c|}{ B } & Std. Error & Beta & \multicolumn{1}{c|}{ Sig. } \\
\hline 1 & (Constant) &, 369 &, 411 & &, 897 &, 373 \\
& Current Ratio &, 136 &, 082 &, 176 & 1,656 &, 102 \\
& Debt to Equity Ratio &,- 041 &, 104 &,- 042 &,- 395 &, 694 \\
& Total Assets Turnover &, 514 &, 116 &, 461 & 4,417 &, 000 \\
\hline
\end{tabular}

a. Dependent Variable: Return on Assets

Jika dilihat dari nilai standardized coefficients beta, nilai total assets turnover $\left(\mathrm{X}_{3}\right)$ merupakan nilai yang terbesar $(0,461)$ dibandingkan dengan dua variabel independen lainnya, sehingga dapat disimpulkan bahwa total assets turnover memberikan kontribusi paling besar terhadap peningkatan kinerja keuangan (return on assets) perusahaan 
pertambangan asing. Berdasarkan hasil perhitungan regresi linear berganda diperoleh nilai thitung 1,656 $<\mathrm{t}$ tabel 1,666, $(\mathrm{df}=5 \% ; 71)$ dengan level signifikan $0,102>\operatorname{sig} \alpha 0,05$ maka Ho tidak dapat ditolak artinya variabel current ratio $\left(\mathrm{X}_{1}\right)$ tidak berpengaruh secara signifikan terhadap variabel kinerja keuangan (return on assets) pada perusahaan pertambangan domestik. Sedangkan nilai t hitung untuk variabel debt to equity ratio $\left(\mathrm{X}_{2}\right)$, adalah $-0,395<\mathrm{t}$ tabel 1,666, $(\mathrm{df}=3 ; 71 ; 5 \%)$ dengan level signifikan $0,694>\operatorname{sig} \alpha 0,05$ maka Ho tidak dapat ditolak artinya variabel debt to equity ratio $\left(\mathrm{X}_{2}\right)$ tidak berpengaruh secara signifikan terhadap variabel kinerja keuangan (return on assets) pada perusahaan pertambangan domestik. Sedangkan nilai t hitung untuk variabel total assets turnover $\left(\mathrm{X}_{3}\right)$, adalah 4,417 $>\mathrm{t}$ tabel 1,666, $(\mathrm{df}=3 ; 71 ; 5 \%)$ dengan level signifikan $0,000<\operatorname{sig} \alpha$ 0,05 maka Ho ditolak artinya variabel total assets turnover $\left(\mathrm{X}_{3}\right)$ berpengaruh secara signifikan terhadap variabel kinerja keuangan (return on assets) pada perusahaan pertambangan domestik.

\section{4) Perusahaan Pertambangan Domestik: Return on Equity (ROE)}

Berikut hasil persamaan regresi berganda dengan ROE sebagai variabel independen: $Y=1,312+0,059 X_{1}+0,056 X_{2}+0,542 X_{3}$

\begin{tabular}{|c|c|c|c|c|c|c|}
\hline \multirow{2}{*}{\multicolumn{2}{|c|}{ Model }} & \multicolumn{2}{|c|}{$\begin{array}{l}\text { Unstandardized } \\
\text { Coefficients }\end{array}$} & \multirow{2}{*}{$\begin{array}{c}\text { Standardized } \\
\text { Coefficients } \\
\text { Beta } \\
\end{array}$} & \multirow[b]{2}{*}{$\mathrm{t}$} & \multirow[b]{2}{*}{ Sig. } \\
\hline & & B & $\begin{array}{l}\text { Std. } \\
\text { Error }\end{array}$ & & & \\
\hline \multirow[t]{4}{*}{1} & (Constant) & 1,312 &, 561 & & 2,340 &, 022 \\
\hline & Current Ratio &, 059 & ,112 & 059 & ,528 & ,599 \\
\hline & Debt to Equity Ratio &, 056 & 142 & 044 & ,391 & ,697 \\
\hline & Total Assets Turnover &, 542 &, 159 & ,377 & 3,417 & ,001 \\
\hline
\end{tabular}

a. Dependent Variable: Return on Equity

Jika dilihat dari nilai standardized coefficients beta, nilai total assets turnover $\left(\mathrm{X}_{3}\right)$ merupakan nilai yang terbesar $(0,377)$ dibandingkan dengan dua variabel independen lainnya, sehingga dapat disimpulkan bahwa total assets turnover memberikan kontribusi paling besar terhadap peningkatan kinerja keuangan (return on assets) perusahaan pertambangan asing. Berdasarkan hasil perhitungan regresi linear berganda diperoleh nilai t hitung $0,528<\mathrm{t}$ tabel 1,666, $(\mathrm{df}=5 \% ; 71)$ dengan level signifikan $0,599>\operatorname{sig} \alpha 0,05$ maka Ho tidak dapat ditolak artinya variabel current ratio $\left(\mathrm{X}_{1}\right)$ tidak berpengaruh secara signifikan terhadap variabel kinerja keuangan (return on equity) pada perusahaan pertambangan domestik. Sedangkan nilai t hitung untuk variabel debt to equity ratio $\left(\mathrm{X}_{2}\right)$, adalah 0,391 < t tabel 1,666, $(\mathrm{df}=3 ; 71 ; 5 \%)$ dengan level signifikan 0,697 > sig $\alpha 0,05$ maka Ho tidak dapat ditolak artinya variabel debt to equity ratio $\left(\mathrm{X}_{2}\right)$ tidak berpengaruh secara signifikan terhadap variabel kinerja keuangan (return on equity) pada perusahaan pertambangan domestik. Sedangkan nilai t hitung untuk variabel total assets turnover $\left(\mathrm{X}_{3}\right)$, adalah 3,417>t tabel 1,666, $(\mathrm{df}=3 ; 71 ; 5 \%)$ dengan level signifikan $0,001<\operatorname{sig} \alpha$ 0,10 maka Ho ditolak artinya variabel total assets turnover $\left(\mathrm{X}_{3}\right)$ berpengaruh secara signifikan terhadap variabel kinerja keuangan (return on equity) pada perusahaan pertambangan domestik. 
Berdasarkan hasil perhitungan regresi linear berganda, dapat disimpulkan bahwa variabel current ratio $\left(\mathrm{X}_{1}\right)$, debt to equity ratio $\left(\mathrm{X}_{2}\right)$, dan total assets turnover $\left(\mathrm{X}_{3}\right)$ secara bersamasama berpengaruh positif dan signifikan terhadap variabel kinerja keuangan baik untuk return on assets maupun return on equity pada perusahaan pertambangan asing.

Namun berdasarkan uji koefisien masing-masing variabel, variabel Current Ratio dan Total Asset Turnover tidak berpengaruh signifikan sedangkan Variabel Debt Equity Ratio berpengaruh secara signifikan terhadap variabel kinerja keuangan. Walaupun current asset kedua kelompok perusahaan ini adalah masing-masing 534 dan 277 namun pengaruhnya terhadap kinerja keuangan adalah tidak signifkan. Tidak signifikannya hasil tersebut dapat disebabkan oleh alasan bahwa perusahaan pada sektor pertambangan ini merupakan perusahaan yang padat modal sehingga, sebagian besar asset perusahaan lebih banyak diinvestasikan pada aktiva tetap daripada aktiva lancar. Walapun hasil tidak signifikan, namun koefisien current ratio adalah positif sehingga mengindikasikan bahwa current ratio yang rendah akan menyebabkan turunnya kinerja keuangan. Current ratio yang tinggi dapat disebabkan adanya piutang yang tidak tertagih dan persediaan yang belum terjual, yang tentunya tidak dapat digunakan secara cepat untuk membayar hutang. Di sisi lain perusahaan yang memiliki aktiva lancar yang tinggi akan lebih cenderung memiliki aset lainnya dapat dicairkan sewaktu-waktu tanpa mengalami penurunan harga pasar. Perusahaan dengan posisi tersebut sering kali terganggu likuiditasnya, sehingga investor lebih menyukai untuk membeli saham-saham perusahaan dengan nilai aktiva lancar yang tinggi dibandingkan perusahaan yang mempunyai nilai aktiva lancar yang rendah. Hasil yang tidak signifikan ini sejalan dengan pendapat Santoso (2012) yang menyatakan bahwa perusahaan pertambang merupakan perusahaan yang pada modal. Jadi walaupun cuuren asset kelompok perusahaan ini bagus, namun asset tetap perusahaan ini jauh lebih besar dari nilai asset lancar.

Sedangkan Total asset turn over juga tidak mempunyai pengaruh yang signifikan terhadap kinerja keuangan disebabkan sebagai perusahaan yang pada modal, maka kelompok perusahaan membutuhkan modal yang sangat besar, sehingga total asetnya juga menjadi besar, dengan perputaran asset menjadi lebih lambat dari kelompok perusahaan lain, hal ini dapat dilihat dari perputaran asset kelompok PMA adalah sebesar 0,8119 dan kelompom PMDN adalah 0,5183. Hanya variabel Debt to Equity ratio yang mempunyai pengaruh yang signifikan terhadap kinerja keuangan perusahaan pada sektor pertambangan dapat dijelaskan sebagai berikut. Pertama, perusahaan yang padat modal tentu saja membutuhkan dana yang sangat besar, maka pemilik perusahaan tidak akan mampu membiayi operasional perusahaan dengan mengandalkan modal saham saja, maka diperlukan dana pihak asing seperti utang bank atau juga mengeluarkan obligasi. Pada perusahaan perbankan ini, rasio debt kedua kelompok perusahaan ini diatas satu, lebih tepatnya adalah DER untuk PMA 1,18 dan DER untuk PMDN adalah 2,3741, ini menunjukkan bahwa perusahaan lebih banyak menggunakan sumber dana asing atau eksternal untuk membiayi operasional perusahaan. Tentu saja dengan banyaknya dana asing atau pinjaman, maka secara teoris beratambahnya utang maka akan dapat meningkatkan kinerja keuangan. Dengan adanya utang lebih besar dari pada modal sendiri ini maka tanggujawab manajer dalam mengelola perusahaan menjadi lebih fokus, jika tidak maka beban utang ini akan membuat perusahaan akan mengalami kesulitan keuangan. 


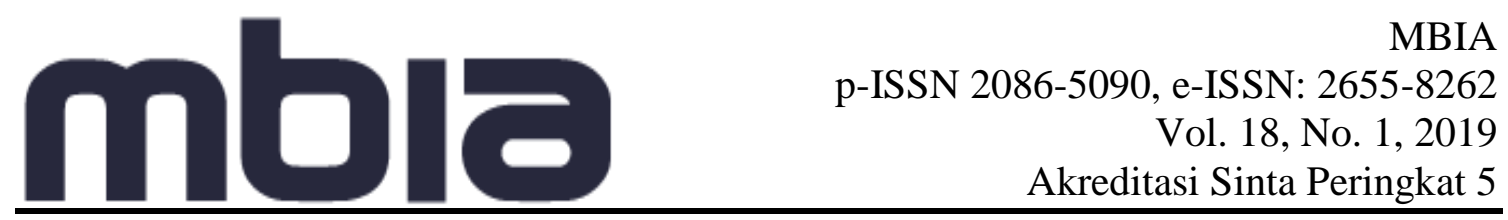

Jika dilihat dari nilai standardized coefficients beta, nilai total assets turnover $\left(\mathrm{X}_{3}\right)$ merupakan nilai yang terbesar dibandingkan dengan dua variabel independen lainnya, sehingga dapat disimpulkan bahwa total assets turnover memberikan kontribusi paling besar terhadap peningkatan kinerja keuangan baik untuk return on assets maupun return on equity perusahaan pertambangan asing maupun pertambangan domestik. Hal ini dapat disebabkan karena perusahaan ini merupakan perusahaan yang pada modal, sehingga total asset turn over ini menjadi variabel yang mempunyai kontribusi terbesar dalam model ini.

\section{Simpulan}

Bahwa ada perbedaan rata-rata secara signifikan, (4) Nilai rata-rata Total Assets Turnover untuk kedua kelompok perusahaan (PMA dan PMDN) menunjukkan tidak ada perbedaan rata secara signifikan, (5) Nilai rata-rata Return on Assets untuk kedua kelompok perusahaan (PMA dan PMDN) menunjukkan tidak ada perbedaan rata secara signifikan, (6) Nilai rata-rata Return on Equity untuk kedua kelompok perusahaan (PMA dan PMDN) menunjukkan tidak ada perbedaan rata secara signifikan, (7) Secara keseluruhan nilai rata-rata CR, DER, TATO, ROA dan ROE perusahaan PMA lebih baik dari pada perusahaan PMDN, (8) Variabel current ratio $\left(\mathrm{X}_{1}\right)$, debt to equity ratio $\left(\mathrm{X}_{2}\right)$, dan total assets turnover $\left(\mathrm{X}_{3}\right)$ secara bersama-sama berpengaruh positif dan signifikan terhadap variabel kinerja keuangan baik untuk return on assets maupun return on equity pada perusahaan pertambangan asing maupun perusahaan pertambangan domestik, (9) Variabel total assets turnover $\left(\mathrm{X}_{3}\right)$ merupakan variabel yang memberikan kontribusi paling besar dibandingkan variabel independen lainnya terhadap peningkatan kinerja keuangan baik untuk return on assets maupun return on equity pada perusahaan pertambangan domestik maupun perusahaan pertambangan domestik.

\section{Daftar Pustaka}

Asyikin, J., \& Tanu, V.S. (2011). Analisis perbandingan kinerja keuangan antara perusahaan farmasi milik pemerintah (BUMN) dengan perusahaan Farmasi Swasta yang Terdaftar di Bursa Efek Indonesia. Jurnal Spread, 1(1), pp. 36-48.

Ayunda, R. (2014). Analisis perbandingan kinerja keuangan pada perusahaan makanan dan minuman di Bursa Efek Indonesia. Jurnal Ilmu \& Riset Akuntansi, 3(11), pp. 119.

Badan Pusat Statistik. (2016). PDB dan Pertumbuhan Ekonomi Triwulan II-2017. Edisi 89 Tahun 2016. Diunduh dari: https://www.bps.go.id/website/pdf_publikasi/Laporan-Bulanan-Data-Sosial-

Ekonomi-Oktober-2017.pdf. yang diakses pada tanggal 19 Oktober 2017.

Santoso, N. (2012). Diunduh dari: http://budi2one.blogspot.com/2012/11/pertambanganmining.html, yang diakses pada tanggal 5 Juni 2018.

Mardiyani. (2017). Analisis perbandingan kinerja keuangan perusahaan farmasi milik BUMN dan Swasta. Jurnal Inspirasi Bisnis \& Manajemen, 1(1),pp. 19-30.

Purnamasari, G.A.Y., \& Ariyanto, D. (2016). Analisis perbandingan kinerja keuangan bank konvensional dan bank syariah periode 2010-2014. E-Jurnal Akuntansi Universitas Udayana, 15(1), pp. 82-110.

Runtulalo, B.T. (2013). Analisis komparasi kinerja keuangan perusahaan manufaktur domestik dan asing yang go public di Indonesia. Jurnal MBA, 1(4), pp. 1-10.

Sanusi, A. (2011). Metodologi Penelitian Bisnis. Jakarta Selatan: Salemba Empat. 
Subaweh, I. (2008). Analisis Perbandingan kinerja keuangan bank syariah dan bank konvensional periode 2003-2007. Jurnal Ekonomi Bisnis, 13(2), pp. 112-121.

Tiasita, N. K.M., \& Wiagustini, L.P. (2017). Studi komparatif kinerja keuangan pada perusahaan domestik dan perusahaan multinasional di Bursa Efek Indonesia. EJurnal Manajemen Unud, 6(5), pp. 2609-2641.

Ulfiyati, U., Lambey, L., \& Walandouw, S.K. (2017). Analisis perbedaan struktur kepemilikan asing dan struktur kepemilikan domestik pada perusahaan pertambangan di Bursa Efek Indonesia. Jurnal EMBA, 5(2), pp. 2260-2267.

Wahyuni, M., \& Efriza, R.E. (2017). Analisis perbandingan kinerja keuangan bank syariah dengan bank konvensional di Indonesia. International Journal of Social and Business, 1(2), p. 66-74.

Zulkifli, Z., \& Wujayanti, D. (2014). Analisis perbandingan rasio profitabilitas perusahaan penanaman modal asing dan penanaman modal dalam negeri pada perusahaan manufaktur yang terdaftar di Bursa Efek Indonesia. Jurnal Kajian Bisnis, 22(1), pp. 11-20.

\section{Copyright Disclaimer}

Copyright for this article is retained by the author(s), with first publication rights granted to the journal. 